\title{
Hanging Emily: Issues in Art, Text and Education
}

\section{Karen Knutson}

We delude ourselves when we think of museums as a clear and transparent medium through which only our objects transmit messages. We transmit messages too -as a medium we are also a message- and it seems to me vital that we understand better just what those messages are. (Weil, 1989, p. 31)

This quote by Hirschhorn Museum director Stephen Weil aptly sums up the key distinction between what might be termed the "old" and the "new" museology. For while the "old" museology focused on museum methods, the new museology has been primarily concerned with the study of the theoretical underpinnings, frameworks and constructs; the assumptions that underpin the representation of objects and ideas in museums. This past decade has been a period of heightened awareness and interest in museums, and the concerns of the new museology have attracted scholars in a variety of fields. However, while this has been important and necessary work, more recent critics have begun to search for practical applications of these theoretical ideas to museum display.

In my dissertation I will explore some of the ways in which these ideas might affect an installation of work by artist Emily Carr (see Blanchard, 1987; Tippett, 1979; Shadbolt, 1990), an historical figure whose import to British Columbia and Canada might most closely be related that of her American contemporary Georgia O'Keefe. Through the course of this re-installation, which will be jointly undertaken by the educator and curator at the Vancouver Art Gallery, I am interested to explore areas of historiography, exhibition development and museum education.

In addition to following how these recent museological developments might impact the display of Carr's work I also want to examine how Carr comes to be constructed in terms of the exhibition narrative. What stories will be told? Which facets of Carr's life and work will be privileged, and which avoided, and how will Carr's established place in the history of Canadian art be interpreted for the public? Will her work be contextualized, in a setting that evokes perhaps her studio, or the types of exhibitions in which she participated? Will her works be displayed as aesthetic entities with no reference to her life and times? Will there be a critical perspective to the display of her work, or will care be taken to preserve (or emphasize) Carr's iconic status in Vancouver? In broad terms, how will Carr's history be presented within this exhibition?

\section{New Museology}

Interest in the ideological workings of museums, or the "new museology" (Vergo, 1989), has been growing over the past decade, and scholars have examined many different facets of how museums operate to perpetuate or promote cultural and social messages, using diverse mechanisms including its architecture (Duncan and Wallach, 1980), and its methods of display (Hooper- 
Greenhill, 1992), in order to appeal to a certain social class (Bourdieu \& Darbel. 1991).

While these ideological critiques of museums tend to be based on the assumption that museums are monolithic and purely hegemonic entities, the museum community is diverse and has been rapidly changing. And there have been numerous museums and exhibitions that have managed to deal with the challenges of appealing to, and representing a diverse public (e.g. Karp and Levine, 1991). Accepting the notion of the museum as political site, new museums are being established that address local, and/or marginalized communities and their specific concerns. From the traditional notion of the museum as a temple, there is now great interest in the notion of the museum as a forum (Duncan, 1995).

More recent museological studies (Bal, 1996; Greenberg, Ferguson \& Nairne, 1996), reflect this changing perspective and focus on the ways in which museums communicate with their visitors. As Bruce Ferguson notes, "both the art object and the museum in which it is found then are the special subjects of a new critical industry whose criticality often ignores the genres, systems, histories and architectonics of exhibitions and their reception" (1996, p. 176). And many authors suggest that it is precisely the exhibition itself, as the systematic and persuasive articulation of ideas, that needs to be more critically examined (Bal, 1996; Luke, 1992; Huyssen, 1995).

\section{The art museum}

The art museum poses a dilferent set of problems for the new museology, a fact that is easily revealed by the lack of in-depth studies dealing with art in museums in the new museological literature (Vergo, 1989). Much of this literature on museums deals with natural history or ethnographic collections. which, with their imperialistic roots, offer a fruitful line of inquiry for those interested in the politics of collecting and display. And in terms of beginning to examine the constructed nature of exhibitions and display, history, as presented in museums, has become an important object of study (Kavanagh, 1996).

The display of art, on the other hand faces different challenges for the new museologist. In most cases the display of art remains bound up in Western, modernist notions of what art is, and what art is for (Huyssen, 1995). As Bourdieu and Darbel (1991) suggest, the display of art without interpretation effectively excludes that portion of the audience that does not have prior knowledge of art appreciation. And as Dobbs and Eisner (1990) point out, there remains a strong resistance towards any direct intervention (such as labelling) between the viewer and the direct "aesthetic experience" of the contemplation of the artwork among many art galleries.

In spite of the resistance, new museology has posed a serious challenge to the traditional display of art operates under implicit notions of chronology, progress and quality, presenting an "objective" display of art works. And while museum educators are making great strides in their often "second tier" 
interactions with visitors (Hooper-Greenhill, 1994; Coté \& Viel, 1995), working to promote more inclusive and individual responses to artworks, the contemporary art exhibit seems to offer more possibilities for the promotion of the idea of museum as forum. One popular means of addressing, or challenging the traditional, implicit "authorial voice" in exhibitions is by using an artist as curator. By inviting an artist in to curate a show, what Heinich and Pollak (1996) call an "exhibition auteur," there is greater flexibility to present the exhibition as a subjective and personal viewpoint. Artist Fred Wilson, to cite a well-known example, created an exhibition that managed to turn traditional curatorial traditions upside down, exposing the mechanisms of selection and authority, in a way that the curator, as institutional voice, would not be able to do (Karp and Wilson, 1996). Wilson's show Mining the Museum used the museum's collection in a startling way, to overturn the traditional meanings of the objects to expose a radically different point of view.

\section{Historical collections of art}

At this point there remains a disjunction between the theory and the practice of museums (Weil, 1995; Preziosi, 1995). To date there have been few studies that have investigated how the two might begin to intersect in the context of more traditional art collections. To my knowledge no studies have dealt with how exhibition designers deal with these issues and how they might begin to implement new educational strategies in art museums. While, important work is being done, within natural history and ethnographic museums, in contemporary art galleries, and by museum educators on all fronts, it seems as though a question remains as to how museum exhibitions might be able to more adequately deal with these museological concerns in the area of the display of historical survey collections of artworks, by a single artist or by a group of related artists.

\section{Examining texts}

The interest in text has also been studied along a more museographic vein. For instance, the recent interest in providing a broader and more contextual frame for the artworks on display stems from, I believe, an increased interest in the museum as educational forum--to become more accessible to a more diverse public. Artworks were traditionally presented without the mediation of text under the guise that artworks could and should speak for themselves. Unfortunately by following this view, only those who had some training in the language of art were able to follow art exhibitions and all other groups were effectively excluded from this venue.

While museum professionals are interested in how to more effectively communicate to their visitors, there is still I ylatively little information on the development and use of text in museums. As curators have traditionally been the ones to develop texts in exhibitions, it is perhaps not surprising to find that many texts on museum education do not directly address the issue of textual material in the museum and its potential to educate (Berry \& Mayer, 1989). Recently though, entering from the area of visitor studies and science museum 
techniques, the issue of text development to encourage audience interest in the exhibition has become a more central concern. (Hooper-Greenhill,1994; Blais, 1995).

My interest in the museographic arena concerns the use of text in exhibitions. It seems that in order to address postmodern notions of curator as the 'bricoleur' of exhibitions, as the teller of tales, as subjective voice, instead of the notion of the transparent authoritative voice of the institution, text has come to play a larger role in exhibitions. Text is the medium, whether it be implicit (as tradition dictates) or explicit (as current thought suggests) through which exhibitions persuade the viewer to accept (or entertain) a certain point of view. And exhibitions by nature always have a point to make. On this level, exhibitions have become interesting sites for the interrogation of cultural beliefs (Luke, 1992; Bal, 1996; Greenberg, Ferguson, \& Nairne, 1996).

\section{The Vancouver Art Gallery}

The Vancouver Art Gallery is a contemporary art gallery, whose mission is to engage people in contemporary art and ideas. Much of the space is allocated to changing exhibitions and the gallery regularly brings in large touring exhibitions.

Recent among them are Art for a Nation: The Group of Seven, War and Memory: Nancy Spero and Leon Golub, and Traditions Tensions: Contemporary Asian Art. The Vancouver Art Gallery also has the best collection of Emily Carr's work; the Emily Carr Trust Collection that was gathered and bequeathed to the Vancouver Gallery in 1945. Carr's work is displayed on the third floor, where the gallery has a permanent installation called Art in British Columbia. The display is changed from time to time, but for the most part it is fairly static, and the Carr collection has received the least attention to date. The Carr collection is a major draw for the Art Gallery, and forms the hub of the permanent collection. Emily Carr is also the central focus for much of the educational programming at the gallery.

The curatorial position of the gallery is quite wide-ranging. Within the gallery at the moment there are numerous installations in which the curatorial position is direct and offers subjective and challenging viewpoints. Other installations follow a more traditional format focusing on artist biography and chronology. It is interesting to note that in spite of the prevalence of active individual curatorial voices throughout the gallery, the Emily Carr collection remains (explicitly) silent. It is primarily a non-textual chronological hang. The gallery hopes to offer a re-installation of Emily Carr's work. and it must address a multitude of museological issues. An investigation into curatorial and educational opinions and the resulting re-installation will reveal the tensions that exist between different types of display practices. In preliminary discussions with the public programmer and the curator these museological issues are of great interest and concem. in fact, they have suggested that it is partly due to these concerns that Carr's works have remained hanging without much curatorial intervention at all.

They have suggested that the difficulties posed by the hanging of Carr's work also stem in part, from her position within the community. Carr is a popular 
cultural figure, and her popularity reaches far beyond the influence of her art. As an artist, a woman, and a writer, Carr stands as an icon in Canadian history; a fact which is reinforced by her portrayal as such in a "Heritage Minute." Heritage Minutes are short history "commercials" shown on television and at movie theatres that serve to bolster a sense of Canadian identity by featuring key Canadian figures in history. As a woman, eccentric, and lover of Native culture who became successful only in her late fifties, Carr fits well into this particular series of films which focus on those who managed to succeed against the odds (Cameron, 1995; McGinnis, 1995)

The installation of Carr's works in the Vancouver Art Gallery has become even more interesting lately with the addition of an exhibition of works by Native artist Lawrence Paul Yuxweluptun in the adjacent gallery. These works, dealing with Native issues in Canada, have been allowed to confront works by Emily Carr and they, in fact, impinge on her gallery space. His works have been displayed so that they form a dialogue with Carr's works, done in the 1920s and 1930s. At that time, many of Carr's works included a great deal of Native subject matter, as she, like many, believed that one should get out there and document this 'dying culture' (Moray, 1993). Yuxwelupten's work addresses issues such as Native land claims, and Native rights. There is a lot of text accompanying the exhibition, and curator Andrew Hunter subjectively contemplates his own role as a non-Native in the denigration of Natives in Canada, and the destruction of the wilderness. These two adjacent galleries provide a very interesting example of differing beliefs about displaying art.

\section{Conclusion}

I'd like to examine how the recent upheavals in museology might come to be reflected in an exhibition of historical artworks in Canada. I am interested in exploring how educators and curators attempt to deal with these complex museological issues in their pursuit to create an accessible and coherent exhibition. In an exploration of how meaning is created in the museum context, I am interested to trace historiographic issues through the process of exhibition development as a possible strategy to make more explicit the role of historians and curators in creating the history or artists and artworks. By making this role more explicit (and I think that there has been a trend to do this) the potential exists to engage viewers more directly in the experience of exhibits, to open the display of artworks to a variety of interpretations, whether they be personal, institutional, or otherwise.

\section{References}

Bal, M. (1996). Double Exposures: The Subject of Cultural Analysis. London: Routledge.

Berry, N. \& Mayer, S. (Eds.) (1989). Museum education: History, theory, and practice. Reston, VA.: National Art Education Assocation.

Blais, A. (Ed.) (1995). Text in the Exhibition Medium Quebec City: Sociéte des musèes québècois. 
Blanchard, P. (1987). The Life of Emily Carr. Vancouver: Douglas \& Mclntyre.

Bourdieu, P. \& Darbel, A. (1991). The Love of Art: European Art Museums andTheir Public. [1969], trans. Caroline Beattie and Nick Merriman. Cambridge: Polity Press.

Cameron, E. (1995). Heritage Minutes: Culture and myth. Canadian Issues/ Themes Canadiens. $7:$ 13-24.

Cote, M., and Viel, A. (Eds.) (1995). Museums: Where Knowledge is Sh ared. Quebec: ICOM Canada, Musée de la civilisation.

Dobbs, S. and Eisner, E. (1990). Silent Pedagogy in Art Museums. Curator 217-235.

Duncan, C. (1995). Civilizing rituals: Inside public art museums. London: Routledge.

Duncan, C and Wallach, A. (1980). The Universal Survey Museum. Art History 3 (Dec. 1980): 448-468.

Ferguson, B. (1996). Exhibition Rhetorics: material speech and utter sense. In Greenberg, R., Ferguson, B., and Nairne, S. (Eds.) Thinking about Exhibitions. (pp. 175-190). London: Routledge.

Greenberg, R., Ferguson, B., and Nairne, S. (Eds.) (1996). Thinking about Exhibitions. London: Routledge.

Heinich, N. \& Pollak, M. (1996). From Museum Curator to Exhibition Auteur: Inventing a singular position. In Greenberg, R., Ferguson, B., and Nairne, S. eds. Thinking about Exhibitions. (pp. 231-250). London: Routledge.

Huyssen, A. (1995). Twilight Memories: Marking Time in a Cuiture of Amnesia. London: Routledge.

Hooper-Greenhill, E. (Ed.) (1994). The Educational Role of the Museum, London: Routledge.

Hooper-Greenhill, E. (1992). Museums and the Shaping of Knowledge, London: Routledge.

Karp, I., \& Levine, S. (Eds.) (1991). Exhibiting Cultures: The Poetics and Politics of Museum Display. Washington: Smithsonian Institution Press.

Karp, I. \& Wilson, F. (1996). Constructing the spectacle of culture in museums. In 
Greenberg, R., Ferguson, B., and Nairne, S. eds. Thinking about Exhibitions. (pp. 251-268). London: Routledge.

Kavanagh, G. (Ed.) (1996). Making Histories in Museums. London: Leicester University Press.

Luke, T. (1992). Shows of Force: Power, Politics, and Ideology in Art Exhibitions. Durham, NC: Duke University Press.

McGinnis, J. (1995). Heritage Minutes: Myth and History. Canadian Issues/ Themes Canadiens. 7:25-36.

Meijers, D. (1996). The Museum and the 'Ahistorical' exhibition: the latest gimmick by the arbiters of taste, or an important cultural phenomenon. In Greenberg, R., Ferguson, B., and Nairne, S. eds. Thinking about Exhibitions. (pp. 7-20). London: Routledge.

Moray, G. (1993). Northwest Coast Native Culture and the Early Indian Paintings of Emily Carr, 1899-1913. Unpublished doctoral dissertation, University of Toronto.

Preziosi, D. (1995). Museology and Museography. Art Bulletin 77.1(March): 13-15.

Shadbolt, D. (1990). Emily Carr. Vancouver: Douglas \& McIntyre.

Spicer, J. (1994). The Exhibition: Lecture or Conversation? Curator 37 (3): 185197.

Tippett, M. (1979). Emily Carr: A Biography. Toronto: Oxford University Press.

Vergo, P. (Ed.) (1989). The new museology. London: Reaktion Press.

Weil, S. (1995). A Cabinet of Curiosities: Inquiries into Museums and their Prospects. Washington: Smithsonian Institution Press.

Weil, S. (1989). The proper business of museums: ideas or things. Mu se 7.1: 28-38. 